\title{
The Goodland \& Colchie's Stylistic Pattern in a Translational Process for Brazilianisms compared with Brazilian Literary Works present in Translational English Corpus (Tec)
}

\section{O padrão de estilo de Goodland e Colchie no processo tradutório de brasileirismos comparado com as} obras literárias brasileiras presentes no Translational English Corpus

(Tec)

Talita Serpa*

Celso Fernando Rocha* Diva Cardoso de Camargo ${ }^{* * *}$

\footnotetext{
* Doutora pelo Programa de Pós-Graduação Em Estudos Linguísticos da Universidade Estadual PaulistaCampus de São José do Rio Preto. Professora titular do curso de Letras Tradutor e Intérprete da União das Faculdades dos Grandes Lagos. E-mail: talitasrp82@gmail.com.

** Doutor em Lingüística Aplicada pela Universidade Estadual Paulista Júlio de Mesquita Filho (2010) e graduação em Bacharelado em Letras Tradução (inglês/espanhol) pela Universidade Estadual Paulista Júlio de Mesquita Filho (2004). Atualmente é Professor Efetivo da Unesp - São José do Rio Preto. Email: celso@ibilce.unesp.br.
} 
Abstract: This article aims to analyse possible stylistic patterns related to the translational process of brazilianisms present in a Darcy Ribeiro's work, Maíra (1978), comparing it to other translations of Brazilian publications which integrate the Translational English Corpus (TEC). We base our research on canonical works of Corpus-Based Translation Studies (OLOHAN 2001; BAKER 19921993 1995; CAMARGO 2005 2007), as well as of Terminology (FAULSTICH 1995, 2001, 2002; BARBOSA 2006), in order to investigate the sociocultural data by the use of WordSmith Tools - version 4.0 (SCOTT 2004) and TEC Tools. We intend to promote a reflexive observation of brazilianisms, with regard to variation and loans, providing subsidies for the comprehension of translation as a social and linguistic action.

Keywords: Corpus-Based Translation Studies; Stylistic Patterns; Brazilianisms; Variations; Loans.

Resumo: Este artigo tem por objetivo analisar possíveis padrões estilísticos relacionados com o processo de tradução dos brasileirismos presentes em uma obra de Darcy Ribeiro, Maíra (1978), comparando-a com outras traduções de publicações brasileiras que integram o Translational English Corpus (TEC). Nossa investigação emprega obras canônicas dos Estudos da Tradução Baseados em Corpus (OLOHAN 2001; BAKER 19921993 1995; CAMARGO 2005 2007), assim como da Terminologia (FAULSTICH 19952001 2002; BARBOSA 2006), a fim de que observemos os dados mediante o uso do software WordSmith Tools - versión 4.0 (SCOTT 2004) e do TEC Tools. Procuramos, portanto, promover uma observação reflexiva dos brasileirismos, considerando a variação e os emprésticos, proporcionando subsídios para a compreensão da tradução como uma ferramenta social e como um comportamento linguístico.

Palavras-chave: Estudos da Tradução Baseados em Corpus; Padrões estilísticos; Brasileirismos; Variação; Empréstimo.

\footnotetext{
**** Possui Doutorado em Tradução pela Universidade de São Paulo (1993), Pósdoutorado em Estudos da Tradução por The University of Manchester (2003), Livre-Docência em Estudos da Tradução pela Universidade Estadual Paulista Júlio de Mesquita Filho (2005). Atualmente é Professor Adjunto-MS5, Aposentada da Universidade Estadual Paulista Júlio de Mesquita Filho, campus de São José do Rio Preto, onde atua como Professor Voluntário. Também atua como Professora Plena do Programa de PósGraduação em Estudos da Tradução, da USP, e do Programa de Pós-Graduação em Letras, da UNIOESTE, Campus de Cascavel. E-mail: divaccamargo@gmail.com.
} 


\section{Introduction}

Brazilian Literature and Anthropology are still unknown among many readers and researchers of foreign communities, mainly concerning the elements related to the nationalist social formation and to the conception of identity. Therefore, it is important to focus on the process of exposing sociocultural and political aspects of Brazil, in order to encounter similarities/differences and to demystify prejudices, which have been ingrained in the ideologies since the Colonization Era. Considering these elements, the mediation among languages through a translational process ${ }^{1}$ is widely necessary and assigns to the translator the responsibility for creating the ideal recognition of theories and proposals, as well as the capability to represent cultural, political and ideological manifestations.

With this in mind, in our research, we intend to promote a study about the translation into English of a work written by one of the most important contemporary Brazilian novelists and anthropologists, namely Darcy Ribeiro. His theoretical and literary formulations represent, in a South American social environment, relevant educational, political and sociological comprehensions of the problems Brazil has been facing through centuries.

Thus, analysing his works constitutes not only the recognition of his vast and complex conceptual approach but also represents the contact and the identification of Brazilian people with their principles of nationality, which can be understood considering its historical and ethnological aspects. Darcy Ribeiro utilizes a complex lexical-semantic field which expresses peculiar factors of Black, Indian and White communities, and characterizes the style of this Anthropologist, which makes the translation of his works a transcultural challenge.

Consequently, by using a disciplinary approach proposed by Camargo (2005, 2007), which has, as its main theoretical support, Corpus-Based Translation Studies (BAKER 19931995 1999; OLOHAN 2001), we verify a corpus composed of Darcy Ribeiro's work: Maíra (1978), as well as its translation into

\footnotetext{
${ }^{1}$ It is important to emphasize that, for Descriptive Translation Studies, translated texts are the objects that "constrain" all the elements related to the action, to the process and to the results of a translation (TOURY, 1974, 1995).
} 
English: Maíra (1985), performed by Goodland and Colchie. We also consider Faulstich's and Barbosa's theories (2002), for the concepts of brazilianisms, variation and loans in Terminology, involving their social, ideological and historical elements, as well as Barbosa's (2006) lexical studies.

Based on the prominence of these translators during the process of presenting Darcy Ribeiro's Brazil to the Target Audience, we study their style and amplify the discussion by comparing it with other translators' main behaviour present in Translational English Corpus (TEC), which is composed exclusively of translated texts into English from a number of European and non-European languages.

Our main hypothesis is that when we cross-reference all the data related to translational process for brazilianisms in Darcy Ribeiro's work with TEC, by using the resources of corpora investigation, we identify a configuration for the use of loans and variations for this terminological lexicon. This allows us to conclude that these elements of language can promote a stylistic pattern, which is a response of cultural factors and of their influence on the development of Source and Target Audiences as social groups.

\section{Corpus Linguistics and its relation with Translation Studies and Terminology}

In order to develop our study, we consider Baker's (1995) definition of corpus, which, according to her works, represents "[...] any collection of running texts (as opposed to examples/sentences), held in electronic form and analysable automatically or semi-automatically (rather than manually)" (BAKER 1995: 226).

We used two types of corpora, a parallel one (which is our main corpus) and a corpus of texts translated only into English (TEC). Parallel corpora are defined by Baker (1993: 238) as "corpora of source texts and their translations". The parallel corpus we verify in this work consists of a main corpus with source texts (STs) in Portuguese extracted from two of Darcy Ribeiro's works, and a corpus with their target texts (TTs) in English. 
According to Baker (1992), studying corpus helps to establish a style, a kind of "fingerprint" that is expressed in a variety of linguistic and nonlinguistic features. Regarding the translation process, style can be related to an investigation that focuses on ways of expression that are typical of a particular translator, aiming at selecting his characteristic use of language and its individual profile of linguistic habits, comparing them to other translators. In other words, style may involve describing translated texts and linguistic preferences in translation, such as the incidence of loanwords as well as characteristics of variation.

Olohan (2001) points out that the conception of style provides a wide range of linguistic patterns across translators and texts. The researcher confirms the idea that corpus analysis assists in the recognition of the features and choices, which may be linked to a textual genre (e.g. novels vs. theoretical works), to the use of specific structures, to translators' individual 'styles' or even to editorial intervention.

Regarding the variation in Terminology, Faulstich (2002) observes the language as an unstable sociocultural element which reveals that "terms (...) are entities subject to variation and to change and that communications between members of society are able to generate interactional concepts for the same term or to generate different terms for the same concept" (FAULSTICH 2002: 70).

Esteves (2010), in her work Um estudo sobre a equivalência conceitual entre termos do português do Brasil $e$ do inglês: aspectos lexicais $e$ semânticos ${ }^{2}$, follows Faulstich's theoretical framework (2002). The author notices that the concept of terminological variation bounds the definition of term as well as the comprehension of its use in different linguistic systems.

Thus, terms should be described as:

(i) Signs that find their functionality in specialized languages according to the language dynamics;

(ii) Variable entities that are part of different communicative situations;

(iii) Specialized lexicon items that passes through changes. So, they must

be analyzed in synchronic and diachronic language plan (FAULSTICH 2002: 75).

\footnotetext{
${ }^{2}$ A Study about Conceptual Equivalence among Terms of Brazilian Portuguese and English: Lexical and Semantic Aspects.
} 
Under the researcher's perception, a term has different specialized language functions. Faulstich's analysis $(2002,2004)$ as well as Esteves' investigations (2010) support the idea that terms assume specific functions "according to the context of use"; and that, in similar conditions of use, "variants will be considered similarly" (FAULSTICH 2002: 75).

Both researchers list a series of norms which may guide the theories about terminological variation:

a) Dissociation between terminological structure and homogeneity or unity or monorreferentiality, associating terminological structure to ordered heterogeneity notion;

b) Abandonment of the categorical isomorphism between term and concept meanings;

c) Acceptance that the terminology is a fact of language and that it accommodates variable elements;

d) Acceptance that the terminology varies and this variation may indicate a change in course;

e) Terminology analysis of linguistic co-texts and discursive contexts of written language and oral language (FAULSTICH 2002: 76).

Regarding the translational process, these factors support the establishment of a correlation between possible changes in analytical perspectives from one language to another, through the identification of functions that take variants within the linguistic and social communities. Faulstich (2002: 76) observes that terms are closely related to the function they play in a social and cultural system, and their performances start as a pragmatic and empirical entity which determines the possible "variation mechanism".

Faulstich (2002) postulates that some variants:

[...] associate meanings of different languages lexical items, that is to say, lexical items of a language B fill gaps in a language A. Variants suffer, in their performances, intersections caused by the foreign nature of the expressions. This phenomenon occurs when the term presents a foreign language structure which is disturbed by vernacular language structures: a mixture of active forms which may cause variation (FAULSTICH 2002: 77).

The author believes that the occurrence of such variants is by pairs of loanwords and vernacular forms and she adds that: 
Loanwords are lexical items that originate from a foreign language and then, in the social context of a target language, become variants because they create the emergence of a vernacular equivalent, developed by the foreign linguistic environment which is averse to its natural permanence (FAULSTICH 2002: 77).

Such set of variants confirms the propositions of our study, since in the course of the analysis we could find a lot of loaned terms, and, thus, we observed the interference of Portuguese in English language as well as in the translation correspondents which formulate the anthropological Terminology related to brazilianisms. We could also verify that Portuguese presents autonomy to be shown during the composition of Social Sciences Terminology, as well as Indigenous and African languages, and also some dialects used in different Brazilian regions, for example: grupiara, cabaça, cauim, jurupari, pajé, tuxauá, caboclo, cabra, capanga and paçoca.

In the translational process for texts which have brazilianisms as their basis, it is possible to understand that different stages occur and that the terminological items adequate themselves to numerous types of loans and variations. Therefore, in the translation context, elements such as discourse, regionalism, geography and time are important aspects to be considered during the professional activity.

\subsection{The concept of brazilianisms}

Scholars who are dedicated to specific socio-cultural phenomena in Translation Studies verify that elements of society structures sometimes become part of terminological settings, specially, when they represent cultural and anthropological analysis. Therefore, in researches carried out in Brazil, we can consider these factors as brazilianisms, which, according to Coelho (2003), are understood as levels of Brazilian people's linguistic identity.

For Faulstich (2004), some of these linguistic-cultural entities assume a conceptual framework that belongs more in a terminological sphere than in common language area, naming the so-called terminological brazilianisms. Then, these lexical units constitute a functional character in specific 
scientific contexts. The theoretician defines the terminological brazilianisms as words, idiomatic expressions and another syntagmatic structures created in Brazil, which have autonomous meaning and are strictly related to a specific concept, which allows to recognize the area to which it belongs (FAULSTICH 2004).

\section{Material and Methods}

In order to develop this study, we created a parallel corpus, constituted by the literary work: Maíra, written by Darcy Ribeiro and originally published in Portuguese, in 1978, and its respective translation into English, Maíra, performed by Goodland \& Colchie, published in 1985.

We also utilize the TEC, which is composed of translated texts into English from a number of European and non-European languages. Moreover, TEC contains the largest collection of texts worldwide, with around ten million words, which was also the first fully computerized. It is divided in the categories of fiction, biography, newspapers and in-flight magazines. For our investigation, the fictional corpus is essential, whose translated texts are entirely incorporated. The stored translations are done by native speaker translators, and most of these translated texts were published after 1983. Among the texts selected to compound the corpus related to Literature, we focus on works translated from Brazilian Portuguese into English, such as: 1) Turbulence by Chico Buarque, translated by Peter Bush; 2) Discovering the World by Clarice Lispector, translated by Giovanni Pontiero; 3) The Hour of the Star by Clarice Lispector, translated by Giovanni Pontiero; and 4) Whatever happened to Dulce Veiga? by Caio Fernando Abreu, translated by Adria Frizzi.

With regard to the tools used for this research, on one hand, we used the program WordSmith Tools - version 4.0 (SCOTT 2004), and its applications WordList, KeyWords and Concord. We obtained a list of possible terms in the novel written by Darcy Ribeiro in Portuguese. Then the wordlist in English was also observed, and, thus, two lists were prepared: the first in Portuguese, and the other with the corresponding terms in English. 
On the other hand, in TEC, data identification proceeded with the help of a software provided by TEC itself, which is called TEC Tools. We selected the corpora by utilizing the $\mathrm{TT}$ search tool (select sub-corpus). Then, we created a wordlist of each translated work and selected the possible cases of loans based on the observation of words in their context. In the end, we looked for loans in the respective co-texts, using the text extraction tool (Extract).

\section{Analysis of Translational style concerning brazilianisms present in Maíra}

In order to verify the parallel corpus composed by Darcy Ribeiro's literary work and by its translation into English, we intended to analyse how Goodland and Colchie develop their translational stylistic patterns. To reach this objective, we firstly generated the frequency list, which was extracted from the ST, using the WordList. We also generated concordance lines based on the most frequent words in Portuguese and in English. In the tables below, we find ten of the most frequent words in the ST and in the target text (TT).

Table 1: Ten most frequent words present in Maíra ST

\begin{tabular}{l|l|l}
\hline $\mathbf{N}$ & Word & Freq. \\
\hline 1 & DEUS & 345 \\
\hline 2 & SENHOR & 232 \\
\hline 3 & GENTE & 216 \\
\hline 4 & MUNDO & 213 \\
\hline 5 & MAIRA & 193 \\
\hline 6 & CASA & 186 \\
\hline 7 & HOMENS & 173 \\
\hline 8 & ALDEIA & 156 \\
\hline 9 & TEMPO & 154 \\
\hline 10 & MULHERES & 153 \\
\hline
\end{tabular}

Table 2: Ten most frequent words present in Maíra TT

\begin{tabular}{l|l|l}
\hline $\mathbf{N}$ & Word & Freq. \\
\hline 1 & GOD & 325 \\
\hline 2 & PEOPLE & 255 \\
\hline 3 & FATHER & 239 \\
\hline 4 & MEN & 226 \\
\hline 5 & HOUSE & 215 \\
\hline 6 & WORLD & 200 \\
\hline 7 & WOMEN & 195 \\
\hline 8 & VILLAGE & 160 \\
\hline 9 & INDIANS & 131 \\
\hline 10 & GROUND & 128
\end{tabular}


Regarding the most frequent words, we detected that the most occurring words in ST, for example, casa (186) and aldeia (156), also have a high level of repetition for their correspondents in TT, namely: "house" (215) and "village" (160).

It is also important to verify plausible changes in meaning that may be performed during the writing of TTs by translators, focusing on some aspects and neglecting others, thus, producing new texts. In this sense, by noticing the repeated use of words in the ST, we can evaluate, for example, terms like "village", used by Ribeiro 156 times in his literary work. In its common definition, one "village" is a land location that represents the smallest demographic unit found among human groups. This construct, therefore, relates to the notions of "town" and "city".

In target language (TL), "village" is represented, according to The Sterling Dictionary of Anthropology (DAS 1997: 141), as a collection of houses treated as a unit and allocated in order to compose a community in which all residents are integrated. The dictionary also states that the "village" proposition has begun to exist during Neological Period, although there have been records of houses like these since 8000 B.C., in Egypt.

According to the concept of style, it is compelling to verify that, in this example, Goodland and Colchie establish a sense of respect for Brazilian Indigenous "villages" which rebuild the ideas of these nuclei's regularity and uniformity. Consequently, their TT refers to the "village" as the simplest type of settlement that is more or less dispersed.

In Brazil, it is important to consider that the term aldeia is more often applied to Indigenous settlements. It is linked to the context of "sedentary collector people" and to the purposes of "subsistence production". The internal organization is established similarly to a "village", based on political and religious powers of a spiritual leader determined according to a hierarchy based on kinship lineage.

Hence, the translators deal with fields that combine anthropological writings transfigured into a literary text. Their style reveals some sociocultural aspects, concealing others. For example, when they translate the term povo, they frequently choose the word "people". However, 
Goodland and Colchie use this term 39 times more in TL, which shows a new text organization that sums up, probably, other occurrences of terms such as povo, pessoas, povoações.

It is necessary to consider that the translational style encompasses the conduct of variation related to lexical choices for some terms found in ST. Faulstich (2001) indicates the existence of variability especially with regard to social and cultural issues, which led us to consider the possible occurrence of this phenomenon in the translation of the works that compound the main corpus in this research. Therefore, we could observe that there were many different options assumed by Goodland and Colchie to the translational process for brazilianisms. In Chart 1, we present some examples of variation:

Chart 1: Terms which present variation during Goodland and Colchie's translational process

\begin{tabular}{l|l|l|l|l}
\hline $\begin{array}{l}\text { Brazilianisms } \\
\text { in Maíra ST }\end{array}$ & First option & Second option & Third option & Forth option \\
\hline Feitiço & Spell & Sorcery & $-\cdots-\cdots-$ & \\
\hline Guri & Boy & Tot & & \\
\hline Panema & Adversity & No Lucky & & \\
\hline Patuá & Basket & $\begin{array}{l}\text { Box of Woven } \\
\text { Straw Wealth of Leather } \\
\text { Sack }\end{array}$ & $\begin{array}{l}\text { Woven Grass } \\
\text { Basket }\end{array}$ \\
\hline Nhá & Miss & Dona Mistress & Mrs. \\
\hline
\end{tabular}

In those examples, the word feitiço, according to the Dicionário de Ciências Sociais (1986), represents beliefs in supernatural attacks, which require the search for the attacker. There are, therefore, the concepts of "sorcery" and "witchcraft" that are linked with "guessing" and "premonition".

By choosing to vary between the terms "spell" and "sorcery", Goodland and Colchis understand the concept of "speech" which contains values that govern human acts, as shown by The Dictionary of Anthropology (1961), in which the meaning of "spell" is designated as a number of words recited or sung that some groups believe to be able to perform a magical wish. The effect of a "spell" is mandatory and, if properly presented, the expected effect comes naturally. An archaic Terminology may be used in the "spell" in order to make it unintelligible to the new generations and to cause more discomfort and intimidation.

The meaning found in this dictionary for the term "sorcery" refers to the cause or cure of diseases, used, generally, by people properly designated for action. However, within anthropological Terminology, the term "sorcery" is 
associated with "witchcraft" and reports tribal societies' hidden actions. The distinction is made by Anthropologists regarding the idea of malignancy involved in the process, which, according to Evans-Pritchard (1937), is configured in the ability to cause a disease, which is carried on by a possessor of (dark) "magic".

Translators also opt for associating loans to other explanatory terms. Therefore, the more intrinsically related to regionalisms and rituals a term is, the more translators link its loans to translational procedures.

In this context, we present Chart 2 with examples of loans tied to the use of general language terms in order to offer new themes to Anthropology, and, at the same time, to support this theoretical area with vocabularies recognized by readers, allowing them to select their own understanding for concepts and theories provided by STs and TTs:

Chart 2: Brazilianisms which present variation and loans during Goodland and Colchie's translational process

\begin{tabular}{l|l|l|l|l}
\hline $\begin{array}{l}\text { Brazilianisms in } \\
\text { Maíra ST }\end{array}$ & First option & $\begin{array}{l}\text { Second } \\
\text { option }\end{array}$ & Third option & $\begin{array}{l}\text { Fourth } \\
\text { option }\end{array}$ \\
\hline Ambir & Ambir the & $-\cdots---$ & $-\cdots--$ \\
old & Devil & Anhangá & $-\cdots---$ \\
\hline Anhangá & Evil Spirit & Berserk & Madman & $-\cdots---$ \\
\hline Inharon & Inharon & Living Flute & Piping Guan & \\
\hline Jacui & Jacui & $\begin{array}{l}\text { Lance Javari } \\
\text { Palm }\end{array}$ & $\begin{array}{l}\text { Javelin } \\
\text { Throwing } \\
\text { Match }\end{array}$ & Javari \\
\hline Javari & Javelin & \multicolumn{2}{|l}{} \\
\hline
\end{tabular}

When Goodland and Colchie face terms that are distinctly "Brazilianized", it is possible to observe that they construct a relational behaviour, promoting, at first, a loan for the term in SL and then articulating them to words that explain it or that make it more explicit, for example, in the case of Anhangá. This brazilianism is the name that Tupi Indians used to give to spirits who wander on Earth after death and who torment living beings. According to legends, these ghosts take the form they want, even though they prefer the figure of a fiery-eyed deer with a cross drawn on its forehead.

The term origin is bound to the word añanga, a mythical animal, hunting and hunters' protector. However, for White colonizer culture, Anhangás are "evil spirits", demons, often confused with anhangueras (Old Devils). 
We also noticed the intense reuse of direct loans. In Chart 3, we present some examples of this procedure:

Chart 3: Brazilianisms which present loans as translation option (Maíra)

\begin{tabular}{l|l}
\hline Brazilianisms present at Maíra ST & $\begin{array}{l}\text { Goodland and Colchie's } \\
\text { translation option }\end{array}$ \\
\hline Anacã & Anacã \\
\hline Avá & Avá \\
\hline Bororo & Bororo \\
\hline Caariara & Caariara \\
\hline Curupira & Curupira \\
\hline
\end{tabular}

The translator presents the text as a place of social interaction, which they tends to explore, analyse, interpret and rewrite. The formation of the translational style, here, runs through the construction of other behaviours and skills related to the role of the translator as a social actor as well as a researcher, reader and analyst.

Following this premise, from the selected words, we carry out the observation of concordance, using the Concord tool. Thus, the terms, in contexts, can dialogue with the lexicon and the nuclei of adjacent words, favoring the reading and interpretation of ST and TT. The keywords of a work compound "extended" linguistic elements in order to show the correlation between words and terms. We present below, in Chart 4, two of ST keyword and the expressions formed by them (aldeia/s and índio/s):

\section{Chart 4: Examples of expression derived from keywords in Maíra ST}

\begin{tabular}{l} 
ALDEIA/S \\
Aldeia Mairum - Aldeia antiga - Aldeia dos índios mairum - Aldeia indígena - Pequenas aldeias \\
- Aldeia natal - Pátio da aldeia - Caminho da aldeia \\
\hline ÍNDIO/S \\
Puta de índio - Histórias dos índios - Índios mairuns - Índios bravios - Índios hostis - Índios \\
Xaepês - Índios arredios - Língua dos índios - Ação de guerra dos índios - Deus de índios e de \\
pretos - Menino-índio - Índio genérico - Ex-índio - Fundação Nacional do Índio - Índio \\
convertido - Índios selvagens - Cemitério de índios - Índios bravos - Iparanã dos índios
\end{tabular}


We also checked the formulations offered by Goodland and Colchie with respect to the same keywords in TL. Below, we present Chart 5, containing extracted expressions of Maíra TT:

Chart 5: Examples of expression derived from keyword in Maíra TT

VILLAGE/S
Dancing ground of the village - Mairun village - Village of Corrutela - Tuscan village - Canindejub
of the village - Division of the village - People of the village - Genoese village - Village of wild
Indians - Village of the maiun Indians - Indian village - Half-deserted village - Great village of
vulture people
INDIAN/S
Indian Protection Service - Hostile Indians - Wild Indians - Mairun Indians - Indian's dialect -
Xaepês Indians - Indian girl - Untamed Indians - Old Indian woman - Language of the Indians -
Indian Blood - Indian boy - Groups of Indians - Ex-Indians - Indian village - National Indian
Foundation - Indian cemetery - Converted Indian - Generic Indian - Forest Indian - Real Indian -
Indian population

As we have been presenting during our research, most of the terminological set related to Brazilian society undergoes some changes of meaning and of concepts during the translational process, which leads to a standardized language developed by translators' style.

\subsection{Loans in the English version of Maíra}

In our research, we believe that, by selecting loans, the translator tends to present to the reader, new concepts, expanding the wide range of Terminology which encompasses sociocultural phenomena of different kinds of "people"; and allowing them to build new networks among meanings, as well as among social facts. When using this feature, the translator becomes a gatekeeper of social acts, producing Terminology and understanding TL. Therefore, in the following examples, we bring some fragments in which loans occur and we try to verify their performance in context:

lit.corpprinc.port: 0 melhor, Alma, minha amiga, companheirinha lá do Jangadeiros, o melhor mesmo é você sair daqui depressa, com a ajuda desses gringos, amigos do Isaías.

lit.corpprinc.ing: It would be better, Alma, my friend, little companion of the Jangadeiros, it would be better if you left here quickly, with the help of those gringo friends of Isaías's.

The figure of a jangadeiro, in a context typically marked by brazilianisms, represents a folkloric character in the traditional historiography

TradTerm, São Paulo, v. 33, abril/2019, p. 5-25 www. revistas.usp.br/tradterm 
of Ceará State. This idea compounds an identitary element based on Chico Matilda, known as the Sea Dragon. This man would have led his companions, in 1881, convincing them to refuse to transport slaves into Southern Brazil.

Therefore, the style, here, is forged by corpora and conditioned by collective decisions and by the fact that translators are inserted in a field in which they need to be accepted. So that, such acceptance is demarcated by the options that they take when they face some obstacles as brazilianisms, for example.

\subsection{Loans as style elements in TEC literary corpus compared with Maíra}

We emphasize that working with loans is linked with the promotion of a parallel study between Darcy Ribeiro's TT and the TTs present in TEC. We intend, therefore, to point out that the loans make up part of recurring translator's choices and, in that sense, this proposal fits Baker's (1996), as well as Olohan's (2000) style element.

Hence, in order to observe the translation option in TEC, we selected, using TEC Tools, the main occurrences of loans related to brazilianisms. Tables 3 and 4 show some examples found in this corpus.

Table 3: Loans for brazilianisms in Brazilian works present in TEC

\begin{tabular}{l|l|l}
\hline Brazilian literary TTs in TEC & Number of Loans & Total of Works \\
\hline Turbulence & 9 & 38.429 \\
\hline The Hour of the Star & 47 & 27.410 \\
\hline Discovering the World & 40 & 197.422 \\
\hline Whatever happened to Dulce Veiga? & 164 & 72.226 \\
\hline Total & 260 & 335.487 \\
\hline
\end{tabular}

Table 4: Loans for brazilianisms in Darcy Ribeiro's work

\begin{tabular}{l|l|l}
\hline Darcy Ribeiro's TTs & Number of Loans & Number of Words \\
\hline Maíra & 84 & 76.510 \\
\hline
\end{tabular}

We found that both corpora indicate similar rates for loans used during the translation of brazilianisms. In Darcy Ribeiro's TT, the literary work reveals a higher occurrence of these brazilianisms because its themes are related to Indigenous everyday life. Thus, the translators emphasize materials, foods, and religions used by Indian groups. 
Interestingly, in TEC corpus, Abreu's text, which was translated into English by Frizzi, has the highest rate of brazilianisms, 164 occurrences. We noticed, while researching the most frequent words, that the author focuses on issues linked to the Umbanda and Candomblé religious universes. He constantly refers to orixás and talks about rituals, such as:

[WHDV]: Prayer to obtain the blessing of various orixás, among whom are Ifá, Oxumaré, lansã, Exu, Oxum, lemanjá, Obá, the least loved of Xangô's wives associated with turbulent water passion and suffering; and Ossanha, male orixá of medicine.

The second work, which unveils high frequency for brazilianisms, is Lispector's TT, translated by Pontiero: The Hour of the Star (1992). The same translator keeps the percentage of loans in his TT, Discovering the World (1992), also written by Lispector. Finally, the translation with the fewest loans is Chico Buarque's Turbulence (1992), translated by Peter Bush, which presents just nine occurrences.

Observing the main examples for terms in $\mathrm{SL}$ that were preserved in TTs, we verified that both, the main corpus and TEC corpus, bring elements of national culture, such as food, rituals, places, social values and actors that have an important role in social life. In Pontiero's TT, The Hour of the Star, we can find the word mandioca:

[THS]: She recalled her childhood with nostalgia - dried mandioca - and believed that she had been happy.

One distressing Sunday without mandioca, the girl experienced a strange happiness: at the quayside, she saw a rainbow.

We perceived that the loan chosen by the translator brings back the idea of the product, which is used in many Brazilian foods and is one of the tubers most used in this cuisine, which gained cultural and symbolic meaning in some native communities.

Mandioca is also called aipi, aipim, uaipi, macaxeira, maniva and maniveira in Brazil. The root is the largest source of carbohydrate in the tropics, after rice and corn. Its name comes from Tupi origin, mãdi'og, mandi- 
ó or mani-oca which means "Mani’s home", Mani being the goddess of Guarani people.

Pontiero brings up countless cultural events linked to this term. It is interesting to note that in Darcy Ribeiro's STs this food is often mentioned, appearing often among the most frequent words and among keywords. However, Goodland and Colchie did not use loans for it, choosing instead among the following option: "manioc”, "manioc tubber" and "cassava”.

Finally, we noted loans that occurred in both corpora:

Table 5: Loans for brazilianisms in Ribeiro's work and in TEC

\begin{tabular}{l|l|l|l}
\hline Loans & Maíra & TEC & Total \\
\hline $1^{\circ}$ Dona & 33 & 17 & 51 \\
\hline $2^{\circ}$ aavela & -- & 1 & 14 \\
\hline $3^{\circ}$ Xangô & -- & 5 & 6 \\
\hline $4^{\circ}$ Carioca & 2 & 3 & 5 \\
\hline $5^{\circ}$ Guaraná & -- & 2 & 3 \\
\hline
\end{tabular}

The first loan, according to the total of occurrences, is the feminine noun Dona, which can be understood as a synonym for senhora, according to Houaiss (2009). We present the following excerpts taken from Darcy Ribeiro's work:

Maíra: "I'm not a priest, Dona Alma, as I said, I am only a chronic seminarian. I have many doubts about being ordained. I am not even sure that it is my true desire. I live in a trance, Dona Alma, if you will forgive the confidence."

[DW]: No one calls her Dona Regina, neither the children, the adults, nor the other old people: everyone simply calls her Regina.

[WHDV]: She told me to wait in the living room, dona Lilian was coming, and disappeared inside the apartment.

In these excerpts, extracted from both the parallel corpus and the TEC corpus, we found that the translators have a common behaviour for the term Dona, i.e., there is the loan without any explanation, seeking, therefore, to approach SL and TL contexts.

Dona is a woman who overlaps herself in a socioeconomic hierarchy which overcomes the poor, assuming domain categorizations. There is also the expressiveness of the term sinhá, or the idea of possession, linked to the "proprietary" proposal. We verified, therefore, that in the passages in TL present in our corpora, loans took up these values and gave the "owners" certain uniqueness and pride. 
We could also find the brazilianism carioca in Maira, translated by Goodland and Colchie, and in two works of TEC, The Hour of the Star (1992) and Discovering the World (1992), both translated by Pontiero.

Maíra: My prayers to the Virgin Mary to help me, to bring me succor, to make me flaccid. I am erect, now and here, on my bed in this pension, as I yearn for a woman. Why am I not going out into the streets to be with a local woman, a carioca

[HS]: To be carioca identified Gloria with the privileged class who inhabited Southern Brazil.

[DW]: I was already in my teens when we moved to Rio, this vast metropolis I soon began to think of as Brazilian carioca.

In the examples, we realized that the meaning of carioca can be easily inferred from the co-text in TL, mainly because, in Lispector's works, Pontiero intends to clarify the concept through the use of words such as Brazilian and Brazil, intensifying the identitary factor, for example, in: who inhabited Southern Brazil.

Therefore, we comprehend that a corpus like TEC allows us to compare some procedures with our study corpus and to identify possible common behaviours and similar phenomena in TTs. The loans are, at the end, a linguistic and sociocultural stylistic pattern.

\section{Conclusions}

We can conclude that Darcy Ribeiro brought to light various aspects of national culturality to be worked out as part of the anthropological language, creating new terms and referring to various elements of "Brazilianness" to build his analysis. These characteristics formed the brazilianisms nuclei observed in our research.

The WordSmith Tools software, through its tools and utilities, greatly facilitated the search in a large amount of data, which was obtained much more quickly and accurately than had it been obtained manually. The concordance lines served as support and clarified doubts regarding the Terminology, because they indicated the co-texts in which terms are inserted. 
Using TEC and investigating its literary works favored the knowledge about corpora, as well as the exploration of translation options that may or may not be repeated when working with brazilianisms.

We noted the formulation of a translational style that supports variations and loans, linking them to the high frequency that occurs in both corpora. The terms were culturally relevant because they showed translational style features and allowed us to verify that even in works of different areas, there is a behavioural pattern that translators employ similarly.

As with WordSmith Tools, TEC Tools also represented an important analysis instrument, allowing us to handle a large amount of data and to verify elements of social and linguistic nature based on statistics. Therefore, we can comprehend not only the translational style shared by the translators of our corpora, but also the different possibilities and the creation of new terms in the anthropological universe.

Finally, the theoretical-practical approach developed by Baker and Olohan favored the analysis of style and the investigations about the social act of translating through the perception of linguistic and terminological phenomena. Besides, the Brazilian works in TEC associated values and principle of nationality to our main corpus, allowing the researchers to deepen their analysis and to intensify the knowledge about Brazil.

\section{References}

BAKER, M. In other words: a coursebook on translation. Londres: Routledge, 1992.

- Corpus linguistics and translation studies: implications and applications. In: BAKER, M.; GILL Francis.; TOGNINI-BONELLI, E. (Ed.) Text and technology: in honour of John Sinclair. Amsterdam: John Benjamins Publishing, 1993. 233-250.

. Corpora in translation studies: an overview and some suggestions for future research. Target, v. 7, n. 2, 1995. p. 223-243.

Barbosa, M. A. Para uma etno-terminologia: recortes epistemológicos. Ciência e Cultura, v. 58, n. 2, 2006. p. 48-51. 
CAMARGo, D. C. Padrões de estilo de tradutores: um estudo de semelhanças e diferenças em corpora de traduções literárias, especializadas $e$ juramentadas. 2005. $512 \mathrm{f}$. Diss. Tese (Livre-Docência em Estudos da Tradução) - Instituto de Biociências, Letras e Ciências Exatas, Universidade Estadual Paulista, São José do Rio Preto, 2005.

- Metodologia de pesquisa em Tradução e linguística de corpus. São Paulo: Cultura Acadêmica/São José do Rio Preto: Laboratório Editorial. 2007.

Coelho, O. Léxico, Ideologia e a Historiografia Linguística do Século das Identidades. Revista Letras, n.61, Curitiba, 2003, p.153-166. Número especial.

DAS, R. N. The Stirling Dictionary of Anthropology. New Delhi: Stirling Publishers Private Limited, 1997.

Evans-PritchaRd, E. E. Witchcraft, Oracles and Magic among the Azande. Oxford: Clarendon Press, 1937.

ESTEVES, M. B. Um estudo sobre a equivalência conceitual entre termos do português do Brasil e do inglês: aspectos lexicais e semânticos. 2010. Dissertação (Departamento de Linguística, Português e Línguas Clássicas) - Universidade de Brasília, Brasília, DF.

FAULSTICH, E. Socioterminologia, mais que um método de pesquisa, uma disciplina. Ciência da Informação, v. 24, n. 3, Brasília, DF, 1995, p. 281-288.

FAULSTICH, E. Aspectos da terminologia geral e terminologia variacionista. TradTerm: Revista do Centro Interdepartamental de Tradução e Terminologia, v. 7, São Paulo, 2001. p. 11-40.

"Variação em terminologia: aspectos de socioterminologia". In: Panorama actual de La terminología. Ramos, G. G.; Lagos, M. F. P. (Ed.). Granada: Interlíngua, Editorial Comares, 2002, p. 65-91.

. "Duas questões em discussão: o que são brasileirismos nos dicionários de Língua Portuguesa? Existem brasileirismo terminológicos." Jornada sobre "Variacion Geolectal i Terminologia" Red Panlatina de Terminologia Realiter/IULAterm/Institut Universitari de Linguistica Aplicada. Barcelona, Espanha 24, 2004.

OLOHAN, M. Intercultural faultlines: research models in translation studies I: textual and cognitive aspects. Manchester: ST. Jerome Publishing, 2001.

RIBEIRO, D. Maíra. Rio de Janeiro: Civilização Brasileira, 1976. 
- Maíra. Translated by Goodland and Colchie. London: Pan Books, 1985.

ScotT, M. WordSmith Tools version 4, Oxford: Oxford University Press, 2004.

Translational English Corpus. Manchester: The University of Manchester, 2015.

Recebido em: 24/09/2018

Aceito em: 28/01/2019

Publicado em maio de 2019

TradTerm, São Paulo, v. 33, abril/2019, p. 5-25 www.revistas.usp.br/tradterm 